\title{
Orthanilic Acid and Analogues as Carbon Sources for Bacteria: Growth Physiology and Enzymic Desulphonation
}

\author{
By THOMAS THURNHEER, THILO KÖHLER, ALASDAIR M. COOK*AND \\ THOMAS LEISINGER \\ Department of Microbiology, Swiss Federal Institute of Technology, ETH-Zentrum, \\ CH-8092 Zürich, Switzerland
}

(Received 4 September 1985 ; revised 19 November 1985)

Carbon-limited aerobic batch enrichment cultures were grown and 17 bacteria able to degrade orthanilic acid (2-aminobenzenesulphonic acid), sulphanilic acid, sulphonamide, 4-sulphobenzoic acid, and benzene-, toluene- and phenolsulphonic acids were isolated. The organisms could each use one to three of the substances. Strain O-1, a Pseudomonas sp., which utilized three of these compounds, was studied in detail. A complete mass balance was obtained for the growth of the organism in medium containing, for example, orthanilic acid, and a specific growth rate of $0 \cdot 1 \mathrm{~h}^{-1}$ was observed. Cell extracts desulphonated six aromatic sulphonates. The enzyme(s) was soluble and was not synthesized in succinate-grown cells. Enzyme activity [about $40 \mu \mathrm{kat}(\mathrm{kg}$ protein $)^{-1}$ ] was dependent on the presence of catalytic amounts of $\mathrm{NAD}(\mathrm{P}) \mathrm{H}$.

\section{INTRODUCTION}

Sulphonated aromatic compounds are major pollutants of rivers and lakes. About $10 \%$ of the organic load in the river Rhine is reported to be due to this class of compound (Malle, 1978). These substances can come from detergents, from pulp mill wastes and from the manufacture of dyestuffs, but documentation on biodegradation is as yet largely limited to information on detergents (Cain \& Farr, 1968; Focht \& Williams, 1970; Ripin et al., 1971; Endo et al., 1977; Belly \& Harbison, 1980).

We observed 4-aminobenzenesulphonate as the putative undegraded product from the aerobic bacterial degradation of two azo dyestuffs (Zimmermann et al., 1982, 1984). Intracellularly formed 4-aminobenzenesulphonate is excreted into the medium, where it accumulates (Kulla et al., 1983). Since 4-aminobenzenesulphonate therefore appears resistant to microbial degradation, we initiated enrichments for micro-organisms that degrade this compound and other typical 1-ring sulphonated compounds in wastes from the dyestuff industry. We now report degradation of several aromatic sulphonates and their desulphonation by cell-free preparations.

\section{METHODS}

Materials. The aromatic sulphonates used (Tables 1 and 2) were from Fluka except for 4-sulphobenzoic acid, which was synthesized in the Department of Chemical Engineering and Industrial Chemistry, and 3aminobenzenesulphonic acid, which was purchased from Eastman. The compounds were chromatographically pure and their identity was confirmed by comparing UV spectra with literature data (Weast, 1983; Sadtler, 1975) or by calculating the spectrum from basic principles (Pretsch et al., 1976). All other chemicals were of reagent grade or better.

Apparatus and analyses. Spectrophotometric analyses were done with a Kontron 800 or a Bausch \& Lomb Spectronic 88 spectrophotometer, each equipped with a flow-through cell of $1 \mathrm{~cm}$ path length. Optical density was 
measured in an Eppendorf photometer. High pressure liquid chromatography (HPLC) was done with a Du Pont apparatus and a UV detector (Grossenbacher et al., 1985). The aromatic sulphonates were determined by HPLC with reversed phase columns (Cook et al., 1983a) and $100 \mathrm{~mm}$-potassium phosphate buffer, pH 7.0 (or pH 2.0 for succinate and 4-sulphobenzoic acid), as the mobile phase (cf. Jandera \& Churacek, 1980). The wavelength setting in the detector was $220 \mathrm{~nm}$ for aromatic compounds and $205 \mathrm{~nm}$ for succinate. Sulphite (Grant, 1947; as in the modification of Kondo et al., 1982), sulphate (Johnston et al., 1975) and ammonium ion (Weatherburn, 1967) were measured by routine colorimetric methods. The identity of the ammonium ion was confirmed by further reactions

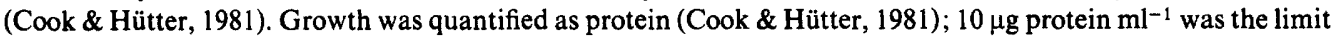
of detection under these conditions. Dissolved organic carbon was assayed by standard methods (Greenberg et al., 1981).

Growth medium and the isolation of organisms. The growth medium was a buffered (10 mM-potassium phosphate, pH 7.0) salts solution to which trace elements (Pfennig \& Lippert, 1966; the sulphate anion was replaced by chloride, which necessitated preparing the solution in two soluble portions) and a single carbon source were added. All enrichment cultures contained $20 \mathrm{mM}-\mathrm{NH}_{4} \mathrm{Cl}$ and $0.25 \mathrm{~mm}-\mathrm{MgSO}_{4}$ but in some experiments in pure culture, the inorganic source of nitrogen and/or sulphur was eliminated. The complete medium was autoclaved. The resulting solution was clear and no loss of sulphonate was observed.

Aerobic batch enrichment cultures $(50 \mathrm{ml}$, non-sterile in shaken $500 \mathrm{ml}$ Erlenmeyer flasks) containing about $30 \mathrm{~mm}$-carbon were used to obtain isolates able to utilize a given aromatic sulphonate as a sole source of carbon and energy for growth. Inocula for enrichments were prepared from three groups of sewage : $(a)$ ten small sewage works receiving largely rural and domestic wastes, $(b)$ eight large sewage works receiving largely domestic but also industrial wastes, and $(c)$ two industrial sewage works used for wastes containing sulphonates. Cultures were evaluated (optical density and substrate disappearance) after about a week and transferred to fresh homologous medium as appropriate. After three subcultures, positive enrichments were streaked on Plate Count agar plates (Difco) and a representative of each colony type was inoculated into appropriate sterile selective medium. When an isolate which degraded the aromatic sulphonate gave rise to a single colony type three successive times on Plate Count agar, it was considered pure and was transferred and maintained in a screw-cap tube on a slant of selective medium solidified with $1.5 \%(\mathrm{w} / \mathrm{v})$ agar. Limited taxonomy was done to ascertain that the strains were unlikely to be pathogens (Krieg \& Holt, 1984) and Oxiferm Tubes (Roche) were used.

Quantification of growth and substrate utilization. Bacterial growth yields with limiting carbon sources were measured at $30^{\circ} \mathrm{C}$ with $50 \mathrm{ml}$ cultures in $500 \mathrm{ml}$ Erlenmeyer flasks mounted on an orbital shaker (2-3 revolutions $\left.\mathrm{s}^{-1}\right)$. Media containing different carbon concentrations were inoculated $(0.3 \%, \mathrm{v} / \mathrm{v})$ and samples (each $\left.5 \mathrm{ml}\right)$ for protein and substrate concentrations were taken immediately and at the end of growth (i.e. exhaustion of substrate). Samples for substrate determination were centrifuged $\left(23000 \mathrm{~g}\right.$ for $20 \mathrm{~min}$ at $\left.4{ }^{\circ} \mathrm{C}\right)$ and the supernatant fluid was stored frozen in a screw-cap vial.

Growth kinetics with $3 \mathrm{~mm}$-substrate were followed at $30^{\circ} \mathrm{C}$ in $300 \mathrm{ml}$ cultures in 2 litre Fernbach flasks. Inocula were exponentially growing cultures in homologous medium. Despite the fact that $3 \mathrm{~mm}$-sulphate was released during the experiment, exogenous sulphate $(0.25 \mathrm{~mm})$ had to be provided to allow growth. Samples were taken at intervals to measure protein, and substrate and inorganic ions. Sulphite had to be measured immediately, because it oxidized spontaneously to sulphate during storage. Material for other tests was stored frozen.

Preparation of cell extracts and enzyme assay. Cells were grown in 1 litre portions of medium in 2 litre Fernbach flasks and harvested $\left(10000 \mathrm{~g}\right.$ for $20 \mathrm{~min}$ at $\left.4{ }^{\circ} \mathrm{C}\right)$ during exponential growth because the specific activity of desulphonation decreased in the stationary phase. They were washed twice in $0.9 \% \mathrm{NaCl}$ solution and the resulting pellet could be stored frozen although there was a loss of activity (about $10 \%$ ) on each thawing. The pellet

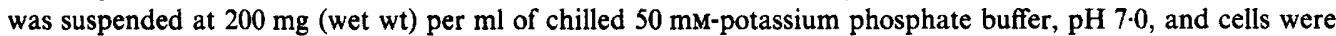
disrupted by three passages through a French press (Aminco) at about $120 \mathrm{MPa}$. The suspension of disrupted cells was centrifuged at $30000 \mathrm{~g}$ for $1 \mathrm{~h}$ at $4{ }^{\circ} \mathrm{C}$, and the supernatant fluid was used for assays of enzyme activity either directly or after desalting on a column of Sephadex G-25 (PD 10; Pharmacia).

Enzyme assays were routinely done in $5 \mathrm{ml}$ reaction mixtures, which were shaken at $30^{\circ} \mathrm{C}$ in a water bath. They contained $250 \mu \mathrm{mol}$ potassium phosphate buffer, $\mathrm{pH} 7 \cdot 0,2.5 \mu \mathrm{mol}$ substrate, $0.5 \mu \mathrm{mol}$ NADH (unless otherwise stated), and the reaction was started by the addition of about $8 \mathrm{mg}$ protein. Samples $(0.5 \mathrm{ml})$ were taken at intervals, acidified (trichloroacetic or perchloric acid to a final concentration of $0.5 \mathrm{M}$ ), and protein was removed by centrifugation $\left(10000 \mathrm{~g}\right.$ for $2 \mathrm{~min}$ at $\leq 4^{\circ} \mathrm{C}$ ). Sulphite was assayed in $0.4 \mathrm{ml}$ portions of the trichloroacetic acid supernatant fluid. Substrate disappearance was determined by HPLC after removal of perchloric acid as the potassium salt. Under these conditions substrate disappearance and sulphite liberation proceeded linearly up to an incubation time of $20 \mathrm{~min}$. No substrate disappeared or gave rise to sulphite in the absence of enzyme and no sulphite or interference in HPLC determinations was observed in cell extracts. Experiments under anaerobic conditions were done as described by Cook et al. (1984) with the additional control that reaction mixtures were confirmed to be active after re-addition of oxygen. 
Table 1. Growth and utilization of sulphonated aromatics by pure cultures

\begin{tabular}{lcccccccccc}
\multicolumn{10}{c}{ Carbon source } & \multicolumn{8}{c}{ Substrate spectrum of isolate: } \\
\cline { 2 - 8 } & B-1 & O-1 & O-2 & S-1 & S-3 & P-2 & P-3 & T-2 & PSB-4 \\
Benzenesulphonate & + & + & - & - & - & - & + & - & - \\
2-Aminobenzenesulphonate & - & + & + & - & - & - & - & - & - \\
3-Aminobenzenesulphonate & - & - & - & - & - & - & - & - & - \\
4-Aminobenzenesulphonate & - & - & - & + & + & - & - & - & - \\
4-Hydroxybenzenesulphonate & - & - & - & + & - & + & + & - & - \\
4-Methylbenzenesulphonate & + & + & + & - & - & - & - & + & - \\
4-Sulphobenzoate & - & - & - & - & - & - & - & + & + \\
4-Aminobenzenesulphonamide & - & - & - & - & + & - & - & - & -
\end{tabular}

\section{RESULTS AND DISCUSSION}

\section{Enrichment and isolation of organisms}

Enrichment cultures were prepared, each of which contained one of three different inocula and one of eight sulphonates. All the sulphonates were observed to be chemically stable. From these enrichments several pure cultures were isolated (Table 1). The inoculum derived from eight small rural sewage works yielded no enrichments whereas that from ten large municipal centres yielded eight enrichments and the inoculum from two sewage plants for sulphonated chemical wastes yielded nine cultures. Six of the eight compounds listed in Table 1 yielded enrichments; 3-aminobenzenesulphonate and 4-aminobenzenesulphonamide did not, although one pure culture from another enrichment was able to utilize the latter compound (Table 1). Pure cultures (17, all bacteria) were isolated, each of which quantitatively utilized the carbon and energy source originally present in the enrichment. Nine different substrate spectra were observed (Table 1); several taxonomically independent strains had the same substrate spectrum.

Although biodegradation of substituted benzenesulphonates can be easily obtained by direct batch enrichment from native samples (Table 1), organisms degrading these compounds are not uniformly distributed in the environment; they appear to occur where evolutionary pressure can be expected, i.e. in wastes where such compounds are continuously available. Some of these degradative activities are already known (Cain \& Farr, 1968; Focht \& Williams, 1970; Ripin et al., 1971) but this is the first report of growth with 2-aminobenzenesulphonate, 4-aminobenzenesulphonate or 4-sulphobenzoate as sole source of carbon in pure culture.

The isolates tended to show a narrow substrate spectrum for the compounds tested, but seven of the eight substrates tested could be degraded by at least some of the isolates (only 3-aminobenzenesulphonate was not utilized). Six strains utilized only one compound (that on which they were enriched), ten strains could utilize two substrates and one isolate (O-1) could utilize three substrates (Table 1). We then concentrated our work largely on strain $\mathrm{O}-1$, in part because of its substrate spectrum and in part because of the ready extractability of its ring desulphonation activity.

Strain 0-1 was a Gram-negative, oxidase positive, motile rod which grew well near $\mathrm{pH} 7$ and utilized acetate as a carbon source. These and other characteristics (reactions in Oxiferm Tubes and polar monotrichous flagellum) allowed its identification as a strain of Pseudomonas (Krieg \& Holt, 1984).

\section{Growth physiology and enzymic desulphonation}

Growth of strain O-1 was proportional to the concentration of substrate supplied (up to 36 mM-carbon) and yields of 5.9, 6.7, 5.6 and 6.0 g protein (mol carbon) ${ }^{-1}$ were observed for succinate, and benzene-, 2-aminobenzene- and 4-methylbenzenesulphonate, respectively. These yields are in the normal range for heterotrophic utilization of a carbon source (Cook et al., $1983 \mathrm{~b}$ ), whether the carbon source is a natural product or an aromatic sulphonate, and the negligible dissolved organic carbon after growth confirmed that the substrate was completely converted to cell material and $\mathrm{CO}_{2}$. 


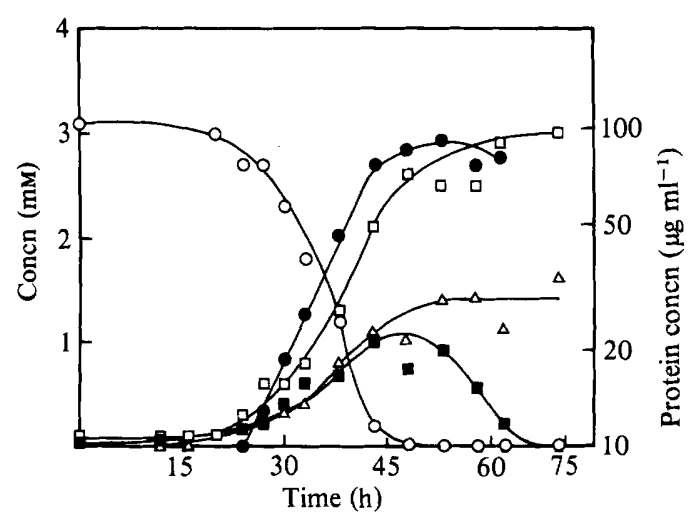

Fig. 1. Growth of Pseudomonas sp. strain O-1 with 2-aminobenzenesulphonate as sole carbon and energy source. $\bigcirc$, Protein; $\bigcirc, 2$-aminobenzenesulphonate; $\square$, sulphate; $\boldsymbol{Q}$, sulphite; $\triangle$, ammonium ion.

Cultures of strain O-1 grew exponentially with benzenesulphonate $\left(\mu=0 \cdot 2 \mathrm{~h}^{-1}\right), 2$ aminobenzenesulphonate $\left(\mu=0.1 \mathrm{~h}^{-1}\right)$ or 4-methylbenzenesulphonate $\left(\mu=0.07 \mathrm{~h}^{-1}\right)$ as sole source of carbon and energy. Representative results with 2-aminobenzenesulphonate are shown in Fig. 1. Substrate utilization was complete and concomitant with growth. Correspondingly, the sulphonate group was released quantitatively and recovered as sulphate. During growth, high transient accumulation of sulphite was observed. Ammonium ion was released from 2aminobenzenesulphonate during growth and the balance of the nitrogen was calculated to be in cell material (cf. Cook et al., 1983b).

The newly-available determinations by HPLC allow direct determinations of substrate utilization to aid in the mass balance and confirm complete utilization of the appropriate compound. These results indicate that it is feasible to treat biologically the aromatic sulphonates in wastes from chemical syntheses.

Crude extracts from strain O-1 were prepared by disruption of whole cells in a French press (disruption by sonication was also possible). The enzyme activity was observed only in the supernatant fluid $(30000 \mathrm{~g}$ or $100000 \mathrm{~g}$ ) and not in either particulate fraction. The specific activity in this unoptimized enzyme assay (Table 2) was lower than the $0.5-1.5 \mathrm{mkat}(\mathrm{kg}$ protein $)^{-1}$ calculated for growing cells. Extracts from cells which had been grown with aromatic sulphonates desulphonated many substrates, whereas extracts from succinate-grown cells had no activity (Table 2). Benzoate-grown cells had low desulphonation activities for three substrates only. The capacity for desulphonation is clearly therefore inducible and the different ratios of activities observed after growth on different substrates imply the presence of more than one desulphonating enzyme. We do not know yet whether lack of transport systems or lack of degradative pathways or some other factor causes the number of growth substrates to be lower than the number of substrates for the desulphonating enzyme(s).

The range of compounds subject to desulphonation by active extracts included the three growth substrates as well as three substrates on which the strain was unable to grow. Thus 3aminobenzenesulphonate, which was not utilized as a carbon source by any strain (Table 1), was desulphonated by the cell extract. But whereas 4-aminobenzenesulphonate was a good substrate for desulphonation, neither the corresponding amide nor the naphthalene analogue was degraded (Table 2). Aromatic sulphonates were converted stoichiometrically to sulphite, which was oxidized very slowly to sulphate in cell extracts; the organic product(s) has not been identified.

Desulphonation by cell extracts was observed to have a cofactor requirement. The removal of small molecules from the crude extract by chromatography on Sephadex G-25 eliminated the activity $\left[27 \mu \mathrm{kat}(\mathrm{kg} \text { protein })^{-1}\right]$, which could be restored by the addition of $0 \cdot 1 \mathrm{mM}-\mathrm{NAD}(\mathrm{P}) \mathrm{H}$, 
Table 2. Enzymic desulphonation observed in cell-free extracts of Pseudomonas sp. strain $O-1$

Desulphonation $\left[\mu \mathrm{kat}(\mathrm{kg} \text { protein })^{-1}\right]$ observed in extracts from cells grown on:

Substrate in

enzyme assay

Benzenesulphonate

2-Aminobenzenesulphonate

3-Aminobenzenesulphonate

4-Aminobenzenesulphonate

4-Hydroxybenzenesulphonate

4-Methylbenzenesulphonate

4-Aminobenzenesulphonamide

1-Amino-4-sulphono-naphthalene

\begin{tabular}{|c|c|c|c|c|}
\hline Succinate & Benzoate & $\begin{array}{l}\text { Benzene- } \\
\text { sulphonate }\end{array}$ & $\begin{array}{l}\text { 2-Amino- } \\
\text { benzene- } \\
\text { sulphonate }\end{array}$ & $\begin{array}{l}\text { 4-Methyl- } \\
\text { benzene- } \\
\text { sulphonate }\end{array}$ \\
\hline
\end{tabular}

$\begin{array}{rr}<1 & 8 \\ <1 & 1 \\ <1 & <1 \\ <1 & <1 \\ <1 & <1 \\ <1 & 2 \\ <1 & <1 \\ <1 & <1\end{array}$

100

30

30

40

70

80

$<1$

$<1$

$\begin{array}{rr}40 & 70 \\ 30 & 60 \\ 5 & 30 \\ 8 & 20 \\ 20 & 40 \\ 20 & 90 \\ <1 & <1 \\ <1 & <1\end{array}$

though NADH gave a threefold higher specific activity [ $40 \mu \mathrm{kat}$ (kg protein $)^{-1}$ ]. No other cofactor tested [NAD(P), FAD] replaced NAD(P)H. NAD(P)H functioned catalytically, because $0.1 \mathrm{~mm}$-cofactor sufficed for the desulphonation of $3 \mathrm{~mm}$-substrate. No desulphonation occurred under anoxic conditions, so we presume the involvement of (di)oxygenases.

Enzymic ring desulphonation is still a rarity. Brilon et al. (1981) elucidated a mechanism for the desulphonation of naphthalene sulphonates but obtained no cell-free desulphonation. Two groups (Willetts \& Cain, 1972; Heyman \& Molof, 1968) observed desulphonation in crude extract and Kondo et al. (1982) reported cell-free desulphonation of benzenesulphonate in separated fractions. Our cell-free extracts have similarities to the NAD(P)H-coupled dioxygenase described by Gibson et al. (1982).

We are grateful to $\mathrm{H}$. Grossenbacher for developing the HPLC determinations. This investigation was supported by grants from the Swiss Federal Institute of Technology, Zürich, and from Ciba-Geigy AG, Basel, Switzerland.

\section{REFERENCES}

BELLY, R. T. \& HARBison, K. (1980). The biodegradation of hydroquinone monosulphonate by pure and mixed microbial cultures. Developments in Industrial Microbiology 22, 485-495.

BRILON, C., BeckmanN, W. \& KNaCkmuss, H.-J. (1981). Catabolism of naphthalenesulphonic acids by Pseudomonas sp. A3 and Pseudomonas sp. C22. Applied and Environmental Microbiology 42, 44-55.

CAIN, R. B. \& FARR, D. R. (1968). Metabolism of arylsulphonates by micro-organisms. Biochemical Journal 106, 859-877.

COOK, A. M. \& HÜTTER, R. (1981). s-Triazines as nitrogen sources for bacteria. Journal of Agricultural and Food Chemistry 29, 1135-1143.

Cook, A. M., Beilstein, P. \& Hütter, R. (1983a). Qualitative analysis of waste-water from ametryne production. International Journal of Environmental Analytical Chemistry 14, 93-98.

COOK, A. M., Grossenbacher, H. \& Hütter, R. $(1983 b)$. Isolation and cultivation of microbes with biodegradative potential. Experientia 39, 1191-1198.

CoOK, A. M., Grossenbacher, H. \& Hütter, R. (1984). Bacterial degradation of $\mathrm{N}$-cyclopropylmelamine. The steps to ring cleavage. Biochemical Journal 222, 315-320.

ENDO, K., Kondo, H. \& Ishimoto, M. (1977).
Degradation of benzenesulphonate to sulphite in bacterial extract. Journal of Biochemistry 82, $1397-$ 1402.

Focht, D. D. \& Williams, F. D. (1970). The degradation of $p$-toluenesulphonate by a Pseudomonas. Canadian Journal of Microbiology 16, 309316.

Gibson, D. T., Yeh, W., Lin, T. \& Subramanian, V. (1982). Toluene dioxygenase: a multicomponent enzyme system from Pseudomonas putida. In Oxygenases and Oxygen Metabolism, pp. 51-61. Edited by M. Nozaki, S. Yamamoto, Y. Ishimura, M. J. Coon, L. Ernster \& R. W. Estabrook. New York: Academic Press.

Grant, W. M. (1947). Colorimetric determination of sulphur dioxide. Analytical Chemistry 19, 345-346.

Greenberg, A. E., Connors, J. J. \& Jenkins, D. (editors) (1981). Organic carbon (total): combustion-infrared method. In Standard Methods for the Examination of Water and Wastewater, 15th edn., pp. 471-475. Washington, DC: American Public Health Association.

Grossenbacher, H., CoOK, A. M. \& Hütter, R. (1985). The determination of biuret and urea by high pressure liquid chromatography. Journal of Chromatography 331, 161-167. 
Heyman, J. J. \& Molof, A. H. (1968). Biodegradation of linear alkylated sulphonates. Environmental Science and Technology 2, 773-778.

JANDERA, P. \& ChURACEK, J. (1980). Reversed-phase liquid chromatography of aromatic sulphonic acids and other strongly polar compounds without addition of an ion-pairing counter-ion. Journal of Chromatography 197, 181-187.

Johnston, J. B., Murray, K. \& Cain, R. B. (1975). Microbial metabolism of aryl sulphonates. A reassessment of colorimetric methods for the determination of sulphite and their use in measuring desulphonation of aryl and alkylbenzene sulphonates. Antonie van Leeuwenhoek 41, 493-511.

Kondo, H., YazaWa, M., ENAMI, H. \& Ishimoto, M. (1982). Sulphite production from benzenesulphonate by bacterial enzyme. Sulphur Amino Acids 5, 237-242 (in Japanese).

KRIEG, N. R. \& Holt, J. G. (editors) (1984). Bergey's Manual of Systematic Bacteriology, vol. 1, pp. 140199. Baltimore: Williams \& Wilkins.

Kulla, H. G., Klausener, U., MEyer, U., LÜDecke, B. \& LeIsingeR, T. (1983). Interference of aromatic sulpho groups in the microbial degradation of the azo dyes Orange I and Orange II. Archives of Microbiology 135, 1-7.

MaLle, K. G. (1978). Wie schmutzig ist der Rhein? Chemie in unserer Zeit 12, 111-122.

PFENNIG, N. \& LIPPERT, D. (1966). Über das Vitamin B $_{12}$-Bedürfnis phototropher Schwefelbakterien. Archives of Microbiology 55, 245-256.
Pretsch, E., Clerc, T., Seibl, J. \& Simon, W. (1976). Tabellen zur Strukturaufklärung organischer Verbindungen mit spektroskopischen Methoden, pp. U5U155. Berlin: Springer.

RIPIN, M. J., NooN, K. F. \& Cook, T. M. (1971). Bacterial metabolism of aryl sulphonates. 1. Benzene sulphonate as a growth substrate for Pseudomonas testosteroni H-8. Applied and Environmental Microbiology 21, 495-499.

SADTLER RESEARCH LABORATORIES (1975). The Sadtler Standard Spectra. Ultra violet spectra no. 117, 2777, 3235, 3616, 5427, 6540, 23142. Philadelphia: Sadtler.

WEAST, R. C. (editor) (1983). CRC Handbook of Chemistry and Physics, 63rd edn, pp. C65-C686. Boca Raton: CRC Press.

Weatherburn, M. W. (1967). Phenol-hypochlorite reaction for determination of ammonia. Analytical Chemistry 39, 971-974.

Willetts, A. J. \& CAIN, R. B. (1972). Microbial metabolism of alkylbenzene-p-sulphonate and dodecylbenzene-p-sulphonate. Biochemical Journal 129, 389-402.

ZimmermanN, T., Kulla, H. G. \& Leisinger, T. (1982). Properties of purified Orange II reductase, the enzyme initiating azo dye degradation by Pseudomonas KF 46. European Journal of Biochemistry 129, 197-203.

ZimmermanN, T., Gasser, F., Kulla, H. G. \& LEISINGER, T. (1984). Comparison of two bacterial azo reductases acquired during adaptation to growth on azo dyes. Archives of Microbiology 138, 37-43. 